\title{
ATW (ACCELERATOR DRIVEN TRANSMUTATION WASTE) SEBAGAI TEKNOLOGI ALTERNATIF PENUTUPAN DAUR BAHAN BAKAR NUKLIR
}

\author{
DJATI H. SALIMY \\ Pusat Pengembangan Energi Nuklir (PPEN) BATAN \\ Gedung Batan Pusat Lt. III C \\ Jl. Kuningan Barat, Mampang Prapatan, \\ Jakarta Selatan 12710 Tel/Fax: (021) 5204243 \\ E-mail: djatihs1638@lecturer.binus.ac.id
}

\begin{abstract}
Abstrak
ATW SEBAGAI TEKNOLOGI ALTERNATIF PENUTUPAN DAUR BAHAN BAKAR NUKLIR. Telah dilakukan pengkajian ATW (accelerator-driven transmutation waste) sebagai alternatif penutupan daur bahan bakar nuklir. ATW adalah perangkat reaktor nuklir subkritis dengan sumber neutron berasal dari akselerator berdaya tinggi, yang dimanfaatkan untuk memfasilitasi proses transmutasi bahan bakar bekas. Proses transmutasi dilakukan terhadap unsur-unsur aktinida minor dan produk fisi umur panjang. Produk dari proses transmutasi adalah unsur-unsur produk fisi yang lebih stabil dengan umur paruh yang pendek, dan listrik. Konsep ATW mempengaruhi sistem daur bahan bakar nuklir yang diadopsi selama ini. Untuk sistem daur terbuka, konsep ATW bisa menjadi alternatif untuk melakukan penutupan daur, yaitu olah ulang bahan bakar bekas untuk diumpankan pada sistem reaktor subkritis. Pada sistem daur tertutup, aplikasi ATW menawarkan sistem daur dobel strata, yaitu suatu sistem daur yang melibatkan daur tertutup konvensional pada strata pertama, dan daur tertutup berbasis teknologi ATW pada strata kedua.
\end{abstract}

Kata kunci : teknologi ATW, transmutasi, daur dobel strata

\begin{abstract}
ATW AS AN ALTERNATIVE TECHNOLOGY FOR CLOSSING THE NUCLEAR FUEL CYCLE. The assessment of ATW (accelerator-driven transmutation waste) as an alternative for closing the nuclear fuel cycle has been carried out. The ATW is subcritical instrument which utilize accelerator as neutron source. This system is used to facilitate transmutation of spent fuels. Trnasmutation is done to burn minor actinides and long lived fissile products in subcritical nuclear reactors. Products of the transmutation process are the relatively stable elements which have short lived fissile products, and electricity. The ATW concept significantly influence the system of nuclear fuel cycle that previously adopted. For the open cycle system, ATW can be an alternative for closing the cycle, by partition process of spent fuels for loading them to the sub critical system reactor. While for the closed cycle system, application ATW promise the concept of double strata nuclear fuel cycles. In this concept, the first strata is the transmutation process in critical advanced nuclear reactors, and at the second strata is the transmutation process at the sub critical facility called ATW system.
\end{abstract}

Keywords : ATW technology, transmutation, double strata cycle 


\section{PENDAHULUAN}

Dalam teknologi daur bahan bakar nuklir, dikenal istilah daur tertutup dan daur terbuka. Daur tertutup adalah suatu sistem daur bahan bakar nuklir dengan melakukan proses olah ulang bahan bakar bekas untuk memungut uranium sisa (recovered uranium) dan bahan plutonium fisil untuk diumpankan kembali sebagai bahan bakar. Pada sistem daur terbuka, tidak dilakukan proses olah ulang. Bahan bakar bekas setelah habis masa pakainya disimpan pada penyimpanan sementara untuk suatu saat dikirim ke fasilitas penyimpanan lestari. Sistem daur terbuka juga bisa berarti wait and see, masih terbuka untuk pilihan apakah memilih daur dengan olah ulang atau daur tanpa olah ulang. Pada kenyataannya banyak negara yang mengoperasikan PLTN, pada awalnya menganut sistem yang bersifat wait and see. Hal ini mengingat sejak saat bahan bakar habis masa pakainya di reaktor sampai proses olah ulang atau penyimpanan lestari membutuhkan waktu yang relatif cukup lama. Selain itu, teknologi olah ulang yang ada sampai saat ini dianggap merupakan teknologi yang rentan terhadap proliferasi nuklir, mengingat dengan teknlogi tersebut dimungkinkan pemungutan bahan plutonium fisil untuk keperluan militer. Karena itu, berbagai penelitian proses olah ulang yang dianggap lebih aman terus dilakukan. Salah satunya adalah teknologi ATW yang melibatkan proses partisi bahan bakar bekas untuk kemudian dilakukan proses transmutasi pada fasilitas reaktor subkritis yang sumber neutronnya berasal dari akselerator berdaya tinggi.

Sistem ATW (Accelerator-driven Transmutation Waste) adalah fasilitas reaktor nuklir subkritis dengan memanfaatkan akselerator berdaya tinggi sebagai sumber neutron. Teknologi ini muncul untuk memfasilitasi proses transmutasi bahan bakar bekas. Sebelum dilakukan proses transmutasi pada fasilitas ATW terlebih dahulu dilakukan proses partisi bahan bakar bekas. Proses partisi bahan bakar bekas yang dipakai adalah proses kering yang disebut proses pirokimia. Berbeda dengan proses olah ulang terdahulu (PUREX dan UREX), proses ini tidak memungkinkan pemungutan bahan plutonium fisil kadar tinggi yang mudah diselewengkan. Proses partisi memungkinkan untuk memisahkan bahan-bahan sangat beracun seperti plutonium, unsur-unsur aktinida minor (neptunium, americium, curium) dan beberapa produk fisi umur panjang dari bahan bakar bekas. Kemudian proses transmutasi dilakukan terhadap bahan-bahan yang dipisahkan sebelumnya, memungkinkan terjadinya konversi bahan-bahan tersebut menjadi produk yang lebih stabil dan berumur paruh pendek. Teknologi ATW ini dikenal juga sebagai reaktor hibrida, karena selain sebagai reaktor transmutasi limbah, juga dapat menghasilkan listrik.

Secara garis besarnya, sistem ATW bertujuan untuk ${ }^{[1,2]}$ : 
1. Memperbaiki penerimaan publik terhadap masalah keselamatan nuklir jangka panjang melalui pengurangan dosis radiotoksisitas

2. Mengurangi aspek akumulasi panas maupun massa pada penyimpanan lestari yang bisa menimbulkan bahaya kekritisan

3. Mengurangi resiko penggunaan dalam proliferasi nuklir

4. Meningkatkan prospek energi nuklir dengan memperbaiki aspek penerimaan publik dan kesinambungan pasokan.

Konsep teknologi ATW ini pada perkembangannya mempengaruhi sistem daur bahan bakar nuklir, karena dengan teknologi ATW dimungkinkan suatu penutupan daur bahan bakar, yaitu mengubah daur terbuka menjadi tertutup. Pada daur tertutup, teknologi ini memunculkan konsep daur tertutup dobel strata. Sistem daur dobel strata, adalah gabungan antara daur tertutup konvensional yang melibatkan reaktor-reaktor daya maju komersial, dan daur tertutup yang melibatkan reaktor sub kritis untuk membakar bahan bakar bekas reaktor komersial.

Pada makalah ini dikaji konsep ATW sebagai teknologi alternatif untuk menutup sistem daur, serta beberapa model implementasi daur bahan bakar nuklir terkait teknologi ATW.

\section{TEKNOLOGI ATW}

Berbagai studi tentang bahan bakar bekas menunjukkan bahwa resiko radiologi jangka panjang berkaitan dengan penyimpanan bahan bakar bekas pada fasilitas penyimpanan lestari meliputi ${ }^{[3,4]}$ elemen-elemen trans-uranium berumur paruh sangat panjang, produk fisi Tc-99 dan I-129 yang mempunyai radiotoksisitas sangat tinggi, serta akumulasi beban panas yang muncul akibat produk fisi Sr-90 dan Cs-137 yang berumur paruh pendek. Untuk mengatasi masalah-masalah tersebut muncullah konsep ATW yang pada prinsipnya bertujuan untuk memperpendek waktu paruh produk fisi yang waktu paruhnya sangat panjang, dan menstabilkan produk fisi transuranium.

\section{Sistem ATW}

Sistem ATW melibatkan beberapa elemen penting yang saling terkait seperti terlihat pada Gambar 2. Elemen-elemen tersebut meliputi :1) akselerator proton linier berdaya tinggi, 2) instalasi proses pirokimia yang merupakan teknologi kunci proses penanganan bahan bakar bekas sebelum diumpankan sebagai bahan bakar pada perangkat reaktor subkritis, dan 3) reaktor subkritis berpendingin lead-bismuth cair sebagai perangkat transmutasi dengan sumber neutron dari akselerator berdaya tinggi. 


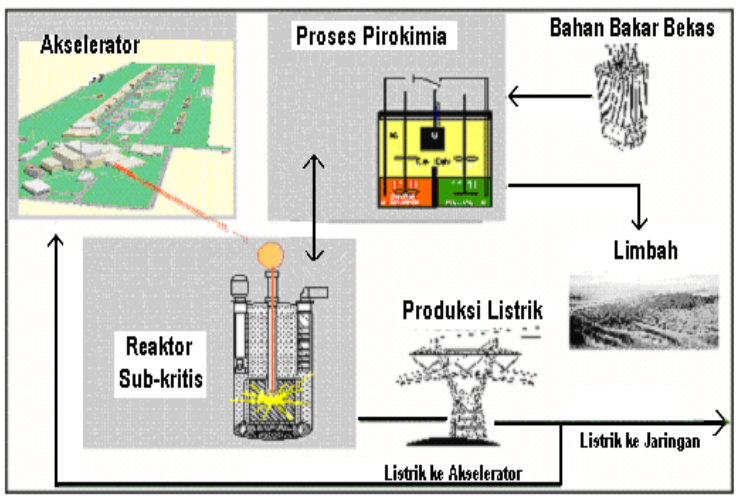

Gambar 2. Skema Sistem ATW

Untuk memenuhi tujuan transmutasi bahan bakar bekas, sistem ATW harus mampu untuk ${ }^{[5,6]}$ :

1. Menghancurkan lebih dari 99,9\% unsur-unsur transuranium yang berumur panjang dan membebani akumulasi panas pada fasilitas penyimpanan lestari.

2. Menghancurkan lebih dari $99,9 \%$ produk fisi Tc-99 dan I-129 yang berumur panjang dan mempunyai tingkat radiotoksisitas tinggi.

3. Memisahkan Sr-90 dan Cs-137 dari bahan bakar bekas, meskipun merupakan produk fisi umur pendek, kedua isotop ini akan meningkatkan akumulasi panas dalam jangka pendek pada penyimpanan lestari.

4. Memisahkan uranium untuk dimanfaatkan kembali, mengingat uranium yang terkandung dalam bahan bakar bekas masih mempunyai kadar U-235 yang lebih tinggi daripada U-alam.

5. Produksi listrik. ATW adalah perangkat sub-kritis yang dari reaksi fisinya menghasilkan energi yang dapat dikonversi menjadi listrik. Listrik ini sejumlah kecil digunakan untuk menggerakkan akselerator, sisanya disambungkan ke jaringan.

\section{Perangkat Reaktor Subkritis}

Pada prinsipnya semua jenis reaktor nuklir (baik reaktor termal, cepat, maupun fasilitas subkritis) dapat digunakan untuk mentransmutasi bahan bakar bekas. Diantara reaktor-reaktor kritis, reaktor cepat memiliki keuntungan yang cukup signifikan jika ditinjau dari parameter fisika neutron. Ini berhubungan dengan sifat unsur-unsur transuranium yang merupakan sumber neutron, tetapi pada sistem reaktor termal justru akan berfungsi sebagai racun neutron. Adanya unsur-unsur aktinida minor pada bahan bakar memberikan efek negatif tersendiri baik pada sistem termal maupun cepat. Fraksi neutron tertunda (delayed neutron) dan koefisien Doppler akan menurun, sementara pada reaktor-reaktor berpendingin logam cair, reaktivitas 
void positif akan meningkat. Karena efek negatif terhadap parameter fisika neutron yang merupakan aspek penting pada sistem keselamatan reaktor, keberadaan aktinida minor pada bahan bakar yang akan ditransmutasi harus dibatasi sekecil mungkin, yang berakibat pada berkurangnya laju transmutasi limbah.

Teknologi ATW dirancang untuk mengatasi efek negatif karena adanya unsur-unsur minor aktinida yang sangat tidak menguntungkan jika ditransmutasi pada fasilitas reaktor kritis yang sudah ada. Di samping itu sistem ATW ini lebih mudah dikontrol dan fleksibel dalam pengoperasiannya, karena bekerja dalam kondisi subkritis. Pada sistem reaktor sub-kritis, sistem kontrol dan perubahan daya tidak tergantung pada neutron tunda, tapi dipicu oleh sumber neutron yang dibangkitkan dari luar sistem. Batang kendali dan reactivity feedback juga bukan masalah penting, karena sistem ini secara netronik terpisah dari sumber netron sehingga memungkinkan beroperasi dengan berbagai komposisi bahan bakar. Jadi dimungkinkan untuk menghancurkan isotop-isotop trans-uranium atau produk fisi atau keduanya tanpa terlalu terpengaruh dengan sifat netroniknya.

Desain konseptual fasilitas subkritis telah dilakukan oleh JAERI Jepang. Sistem reaktor berpendingin $\mathrm{Pb}-\mathrm{Bi}$ yang terpilih merupakan pengembangan teknologi reaktor pembiak cepat berpendingin logam cair dan teknologi reaktor kapal selam berpendingin $\mathrm{Pb}-\mathrm{Bi}$ milik USSR ${ }^{[7]}$. Dengan sumber neutron akselerator berdaya berkas proton sebesar $1 \mathrm{GeV}-45 \mathrm{~mA}$, target/teras mampu melakukan faktor pelipatan neutron efektif sebesar 0,95 menghasilkan daya termal sebesar 800 MWth.

Dengan asumsi faktor beban sebesar 80\%, laju transmutasi diperkirakan 250 kg/tahun. Produksi listrik 240 MWe (efisiensi termal 30\%), sekitar 115 MWe digunakan untuk mengoperasikan akselerator dan sisanya disambungkan ke jaringan listrik komersial. Dengan pola ini, berarti sistem ATW mampu memasok kebutuhan listriknya dari sistem itu sendiri. Pada Gambar 3 ditunjukkan desain konseptual reaktor ATW. 


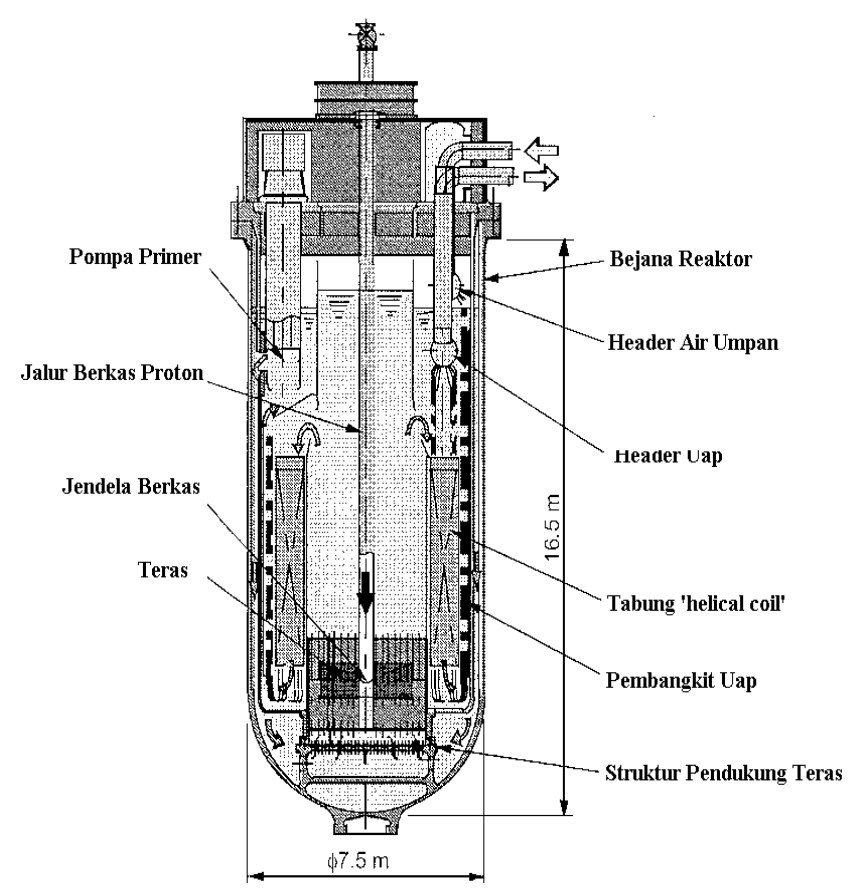

Gambar 3. Konsep Disain Reaktor Subkritis ATW ${ }^{[7]}$

\section{DAUR BAHAN BAKAR NUKLIR}

\section{Daur Bahan Bakar Konvensional}

Secara umum sistem daur bahan bakar nuklir dibagi menjadi daur tertutup (dengan olah ulang) dan daur terbuka (tanpa olah ulang) seperti terlihat pada Gambar 4 dan 5. Pada sistem daur dengan olah ulang, proses olah ulang bahan bakar bekas dilakukan untuk memungut uranium sisa dan bahan plutonium fisil guna dimanfaatkan kembali sebagai bahan bakar baik pada reaktor termal berbahan bakar MOX atau pada reaktor cepat berbahan bakar plutonium dengan blangket bahan fertil uranium. Pada sistem daur tanpa olah ulang, proses olah ulang tidak dilakukan karena dianggap teknologi olah ulang yang ada sampai saat ini merupakan adopsi teknologi pemungutan bahan plutonium fisil untuk keperluan militer, sehingga sangat rentan terhadap proliferasi nuklir. 


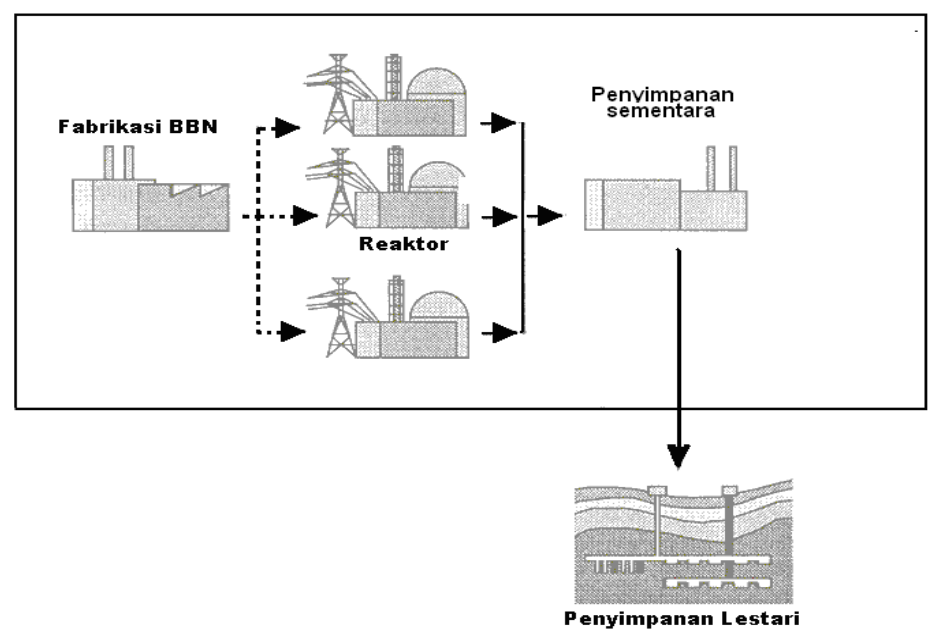

Gambar 4. Daur Bahan Bakar Tanpa Olah Ulang ${ }^{[8]}$

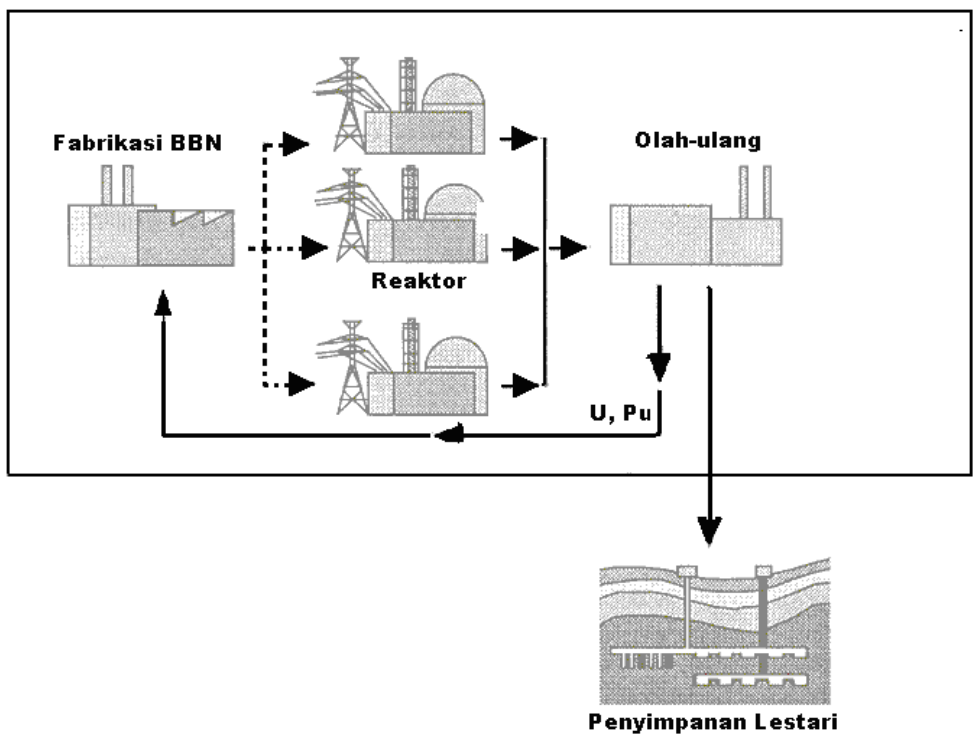

Gambar 5. Daur Bahan Bakar Dengan Olah Ulang ${ }^{[8]}$

Berbagai litbang di negara-negara maju terus dilakukan untuk mendapatkan suatu teknologi olah ulang bahan bakar bekas yang lebih aman terhadap proliferasi nuklir. Konsep ATW merupakan salah satu alternatif penanganan bahan bakar bekas yang lebih aman dari kemungkinan proliferasi nuklir. Munculnya teknologi ATW mendorong beberapa negara yang menganut sistem daur terbuka untuk meninjau kembali sistem daurnya. Bagi negaranegara yang sebelumnya menganut sistem daur tertutup, teknologi ini diadopsi untuk lebih menyempurnakan sistem daur tertutupnya. 


\section{Daur Bahan Bakar Dobel Strata}

Konsep daur dobel strata merupakan implementasi dari munculnya konsep teknologi ATW. Sistem daur terbuka bisa diubah menjadi daur tertutup sebagian, yaitu tetap daur terbuka pada sistem reaktor daya tetapi menerapkan daur tertutup pada sistem reaktor subkritis. Skema daurnya dapat dilihat pada Gambar 6, yang merupakan implementasi strategi 1 daur dobel strata.

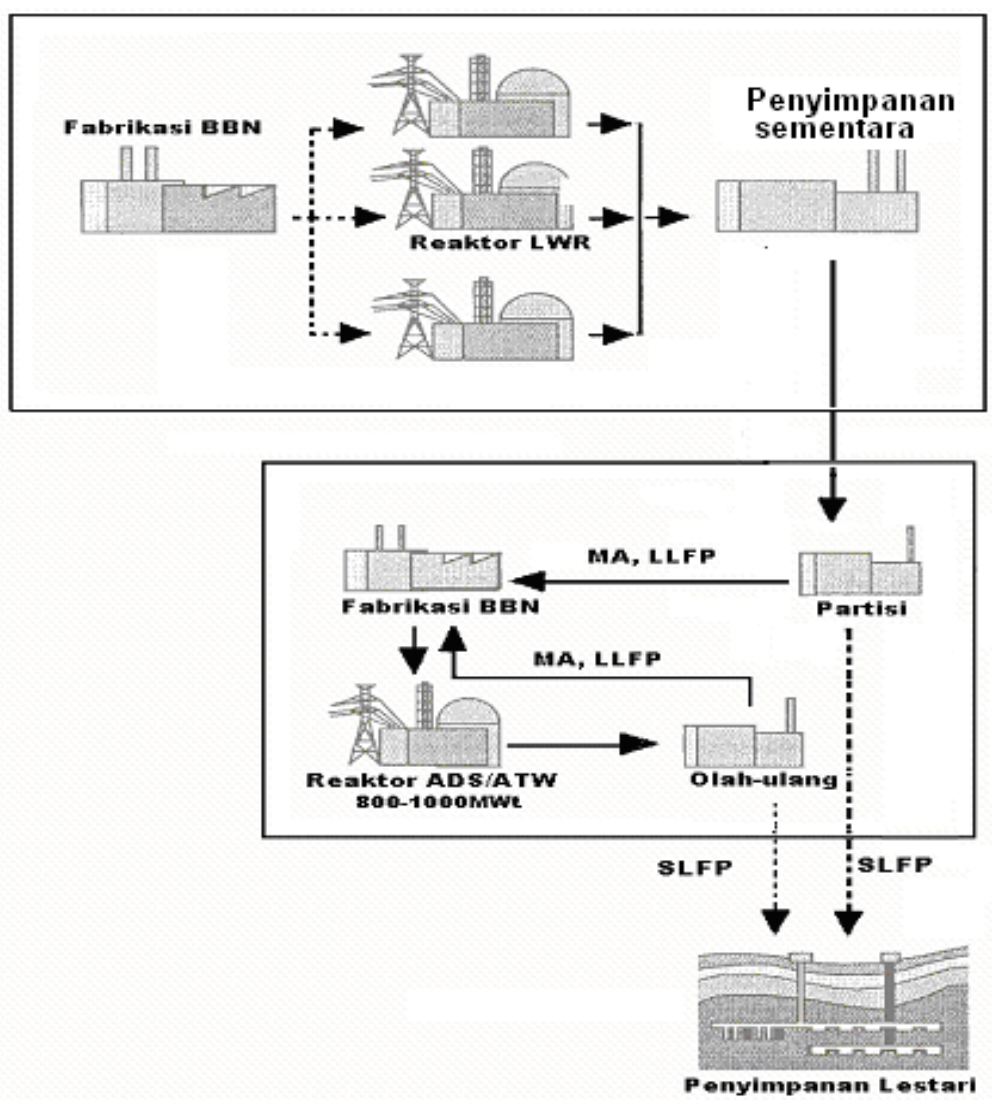

Gambar 6. Daur Dobel Strata, Strategi $1^{[3,8]}$

Bagi negara yang selama ini telah menganut sistem daur tertutup, munculnya konsep ATW lebih menyempurnakan sistem daur tertutup yang sudah ada. Skemanya dapat dilihat pada Gambar 7, yang merupakan strategi 2 daur dobel strata. Pada strategi ini, strata pertama merupakan daur tertutup yang melibatkan reaktor-reaktor daya, sedang pada strata kedua merupakan daur tertutup yang melibatkan sistem ATW. 


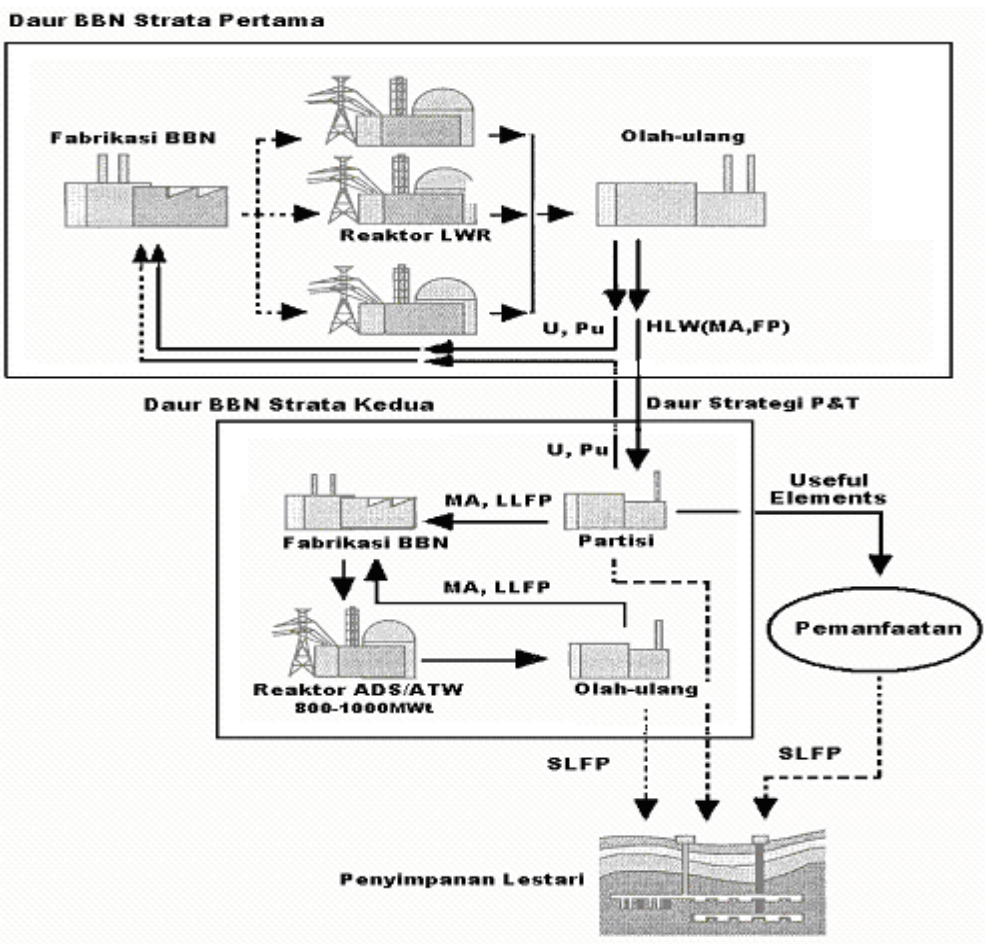

Gambar 7. Daur Dobel Strata, Strategi $2^{[7,8]}$

Konsep daur berbasis teknologi ATW juga menawarkan pemanfaatan bahan bakar bekas bagi negara yang menghentikan program nuklirnya, seperti Jerman. Konsep pemanfaatan bahan bakar bekas dengan sistem ATW dapat dilihat pada Gambar 8.

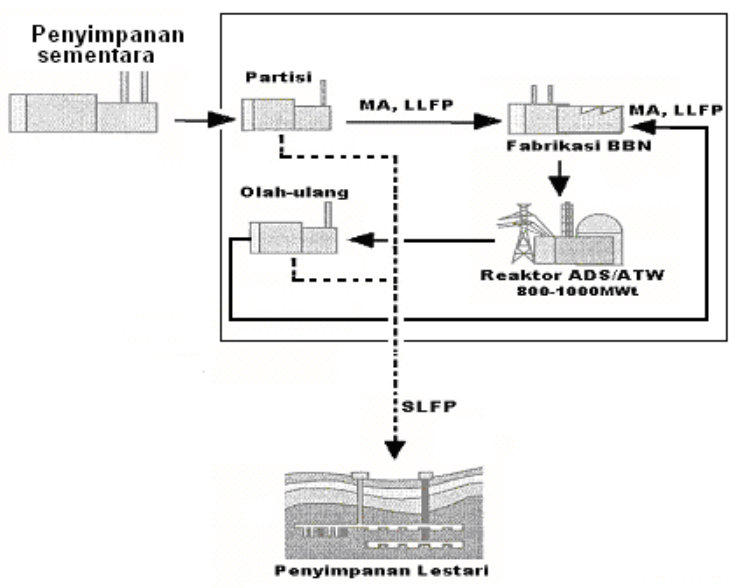

Gambar 8. Daur Dobel Strata, Strategi $3^{[3,8]}$ 


\section{DISKUSI DAN PEMBAHASAN}

Konsep ATW yang pada prinsipnya merupakan gabungan proses partisi bahan bakar bekas, dan kemudian membakarnya (transmutasi) pada perangkat subkritis dengan sumber neutron dari akselerator, menawarkan sistem penutupan daur terbuka serta penyempurnaan sistem daur tertutup.

Negara yang selama ini menganut sistem daur terbuka seperti Swedia misalnya, karena alasan tertentu tidak memungut plutonium dari bahan bakar bekas reaktor komersialnya. Pada kasus ini, plutonium dibiarkan tetap bersama-sama dengan minor aktinida diproses sebagai bahan bakar reaktor subkritis ATW. Pada sistem daur ini (strategi 1), pada strata pertama tetap merupakan daur terbuka tanpa melakukan olah ulang bahan bakar bekas. Olah ulang dilakukan pada daur strata kedua yang merupakan daur tertutup berbasis teknologi ATW. Strategi ini berimplikasi pada dibutuhkannya jumlah fasilitas ATW yang lebih besar dan lebih banyak karena aliran masa terakumulasi pada sistem ATW. Tetapi ditinjau dari sisi proliferasi nuklir, sistem ini lebih aman karena tidak melibatkan proses pemungutan plutonium fisil.

Negara-negara yang program nuklirnya sudah sangat mantap seperti Jepang, Inggris, dan Perancis, beranggapan bahwa daur ulang plutonium dan uranium dari bahan bakar bekas merupakan hal yang sangat penting. Karena alasan tersebut, negara-negara itu mengimplementasikan sistem daur bahan bakar nuklir dobel strata secara lengkap (strategi 2). Pada sistem ini, transmutasi bahan bakar bekas dilakukan dengan 2 langkah. Pada strata pertama, bahan bakar bekas luaran reaktor konvensional diproses untuk dipungut plutonium dan uraniumnya. Uranium didaur-ulang untuk diproses menjadi bahan bakar oksida konvensional, sedangkan plutonium didaur-ulang untuk diproses sebagai bahan bakar MOX, atau sebagai bahan bakar reaktor maju baik sistem termal maupun sistem cepat. Pada strata kedua, bahan bakar bekas reaktor-reaktor berbahan bakar plutonium tadi dicampur dengan minor aktinida sisa bahan bakar bekas reaktor konvensional yang telah dipungut plutonium dan uraniumnya, kemudian diproses sebagai bahan bakar berbasis minor aktinida untuk diumpankan pada sistem transmutasi pada reaktor ATW. Dengan pola daur bahan bakar dobel strata seperti ini, diharapkan aliran massa pada strata kedua lebih kecil sehingga fasilitas subkritis ATW bisa dirancang lebih kompak dengan kapasitas kecil dan bisa dibangun di dekat fasilitas reaktor komersial.

Sistem daur bahan bakar berbasis proses teknologi ATW juga memungkinkan untuk diadopsi oleh negara yang berminat untuk menghentikan program nuklirnya. Sebagai contoh, Jerman yang kebijakan pemerintahnya sudah tidak akan membangun PLTN lagi dan hanya mengoperasikan PLTN yang masih ada, bisa memanfaatkan teknologi ATW dengan model transmutasi strategi 3. Pada strategi ini, semua bahan bakar 
bekas yang disimpan pada fasilitas penyimpanan sementara, diproses sebagai bahan bakar ATW, tanpa dilakukan pemungutan plutonium fisil. Dengan sistem ini, olah ulang bahan bakar bekas dapat dilakukan tanpa harus membangun PLTN baru. Hasil olah ulang ditransmutasi pada sistem reaktor subkritis menghasilkan limbah dengan umur paruh lebih pendek, tingkat radiotoksisitas lebih rendah, juga dihasilkan listrik yang sebagian dipakai untuk mengoperasikan akselerator dan sisanya biasanya disambungkan ke jaringan

Konsep ATW berperan penting pada sistem daur bahan bakar nuklir pada masa yang akan datang. Meskipun pada prinsipnya semua reaktor nuklir (kritis maupun subkritis) bisa dimanfaatkan sebagai reaktor transmutasi, tetapi fasilitas kritis kurang menguntungkan ditinjau dari aspek keselamatan yang berkaitan dengan parameter fisika teras. Keberadaan unsur-unsur minor aktinida pada bahan bakar bekas yang akan ditransmutasi, akan menurunkan reaktivitas pada reaktor kritis. Tetapi pada fasilitas ATW, karena beroperasi pada daerah subkritis, jenis dan sistem bahan bakar untuk mengoperasikannya bisa lebih fleksibel.

\section{KESIMPULAN}

1. Teknologi ATW memainkan peran yang penting pada sistem daur bahan bakar nuklir di masa yang akan datang, terutama terkait dengan penanganan bahan bakar bekas.

2. Daur dobel strata merupakan implementasi konsep ATW. Untuk sistem daur terbuka, pada strata pertama, tetap menganut daur terbuka tanpa olah ulang, sedang pada strata kedua dilakukan penutupan daur dengan melakukan olah ulang bahan bakar bekas untuk ditransmutasikan pada reaktor sub kritis ATW.

3. Untuk sistem daur tertutup konvensional, implementasi ATW menawarkan sistem olah ulang dan daur ulang baik pada strata pertama pada reaktor-reaktor daya maju berbahan bakar MOX dan plutonium, maupun strata kedua pada perangkat sub kritis ATW yang dapat beroperasi dengan komposisi bahan bakar yang lebih fleksibel.

\section{DAFTAR PUSTAKA}

1. GLATS, J. P., HAAS, D., MAGILL, J., and WIDER, H., 1999, "Partitioning and Transmutation in Spent Fuel management”, Proceeding of the $3^{\text {rd }}$ International Conference on Accelerator Driven Transmutation Technologies and Applications, Praha.

2. BAXTER, A., 1999, “Accelerator Driven GT-MHRS for waste Disposal and Proliferation-Resistant Fuel Cycles”, Proceeding of the $3^{\text {rd }}$ International 
Conference on Accelerator Driven Transmutation Technologies and Applications, Praha.

3. THE EUROPEAN TECHNICAL WORKING GROUP ON ADS, 2001, "A European Roadmap for Developing Accelerator Driven Systems (ADS) for Nuclear Waste Incineration”, ENEA, Roma.

4. DOE, 2003, "Report to Congress on Advanced Fuel Cycle initiative: The Future Path for Advanced Spent Fuel Treatment and Transmutation Research", U.S. Department of Energy Office of Nuclear Energy, Science, and Technology.

5. VENNERI, F., WILLIAMSON, M., LI, N., HOUTS, M., MORLEY, R., BELLER, D., SAILOR, W., and LAWRENCE, G., 1999, "Disposition of Nuclear Waste Using Subcritical Accelerator-driven Systems: Technology Choiches and a Possible Implementation Scenario", The Uranium Institute $24^{\text {th }}$ annual International Symposium.

6. DURPEL, L. V., WYDLER, P., SAKURAI, S., NA, B. C., DOMAE, M., and OECD/NEA, 1999, "Comparative Study on ADS \& FR in Advance Fuel Cycles”, Proceeding of the $3^{\text {rd }}$ International Conference on Accelerator Driven Transmutation Technologies and Applications, Praha.

7. TAKIZUKA, T., TSUJIMOTO, K., SASA, T., and TAKANO, H., 1999, "Dedicated Accelerator Driven System for nuclear waste Transmutation", Proceeding of the $3^{\text {rd }}$ International Conference on Accelerator Driven Transmutation Technologies and Applications, Praha.

8. NEA-OECD, 2001, “Trend in Nuclear Fuel Cycle: Economic”, Environmental, and Social Aspects, NEA-OECD Publication. 